\title{
Predicting debris flow susceptible areas through GIS modelling in Aparados da Serra (Brazil)
}

\author{
A. J. Strieder ${ }^{1}$, S. A. Buffon ${ }^{2}$, T. F. P. de Quadros ${ }^{3}$ \\ \& H. R. Oliveira ${ }^{4}$ \\ ${ }^{1}$ Lab. Modelagem Geológica e Ambiental, MODELAGE-UFRGS, Brazil \\ ${ }^{2}$ Ministério Público do Rio Grande do Sul, DAT-MP-RS, Brazil \\ ${ }^{3}$ Departamento Nacional da Produção Mineral, DNPM, Brazil \\ ${ }^{4}$ Transportadora Gasoduto Bolivia-Brasil S.A., TBG-Sul, Brazil
}

\begin{abstract}
This paper aims to present the results of a GIS modelling to predict debris flow susceptible areas in the Aparados da Serra region (Brazil). The region shows a $1000 \mathrm{~m}$ high scarp located close to Atlantic Ocean in southern Brazil. The scarp is developed upon sandstones (Botucatu Fm.) and basalts and dacites (Serra Geral Fm.) of the Paraná Basin, after the break-up of the Gondwana Supercontinent and the opening of the South Atlantic Ocean. It is a topographic barrier to convective clouds migrating from ocean to the continent, mainly in spring and summer seasons. Geologic, geomorphologic, geotechnical mapping were conducted in order to enable GIS data modelling for debris flow in the region. The prediction of areas susceptible to debris flow along the scarp was based upon USPED algorithms. However, some changes were introduced into USPED algorithms in order to model debris flows in this region. The GIS modelling results distinguished susceptible areas for erosion and deposition of the debris, according the modified USPED procedures. These results were compared with a large debris flow event occurred in December 1995, and also recent small scale and localized debris flow events. All these observed debris flows show good correlation with predicted area of occurrence. Thus, it can be concluded that such GIS modelling can be applied to predict areas susceptible for erosion and deposition of debris related to concentrated convective storms.

Keywords: debris flows susceptibility map, GIS modelling, USPED, erosion and deposition.
\end{abstract}




\section{Introduction}

Debris flows are hazardous natural mass movement processes that occur in many countries under different conditions. They are usually seen as a continuum from water flood, through hyper concentrated flow, to debris flow, and tend to flow down slope along channels or stream valleys [1]. Debris flows can be initiated when unconsolidated materials become unstable due to saturation by water, steepening of slopes by erosion or constructions, earthquake shaking, and volcanic eruptions. The water for the debris flows can be supplied by intense rainstorms, by melting of snow or ice, or by overflow of lakes.

Debris flow susceptibility maps have been produced in a number of ways [e.g. 2,3]. Susceptibility maps usually answer one of three important questions when dealing with debris flow: where debris flows will occur? Digital elevation models, geologic and historical data are used to define susceptible source and deposition areas. The complex number of physical parameters governing debris flow triggering makes susceptibility maps generation a difficult task. In some regions, the lack of historical data is an additional problem.

This paper aims to present the application of a modified USPED algorithm to predict source and deposition areas of debris flow. The USPED algorithm [4] includes almost the same physical parameters considered in debris flows. The result is a map distinguishing the relative susceptibility for debris flow source and deposition areas during intense tropical rainstorms (Aparados da Serra region, southern Brazil, fig. 1).

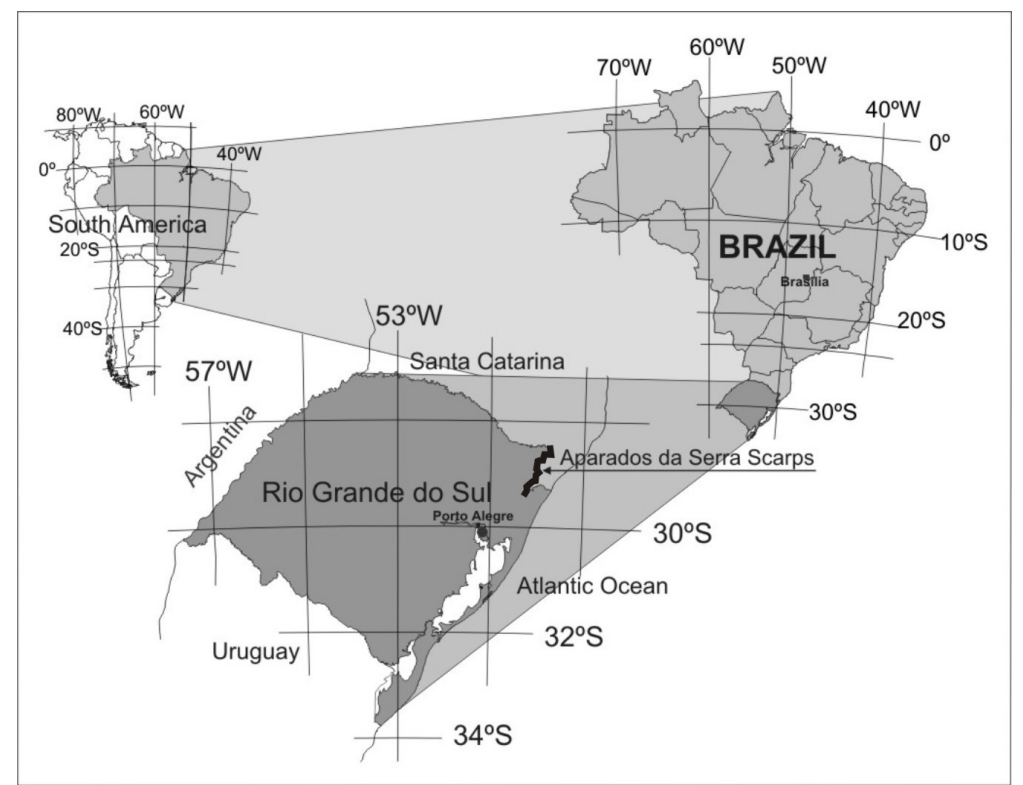

Figure 1: Regional map locating Aparados da Serra region, southern Brazil. 


\section{Historical data in the Aparados da Serra region (Brazil)}

The Aparados da Serra region lacks adequate historical data records for debris flow events. There exist some old reports in regional newspapers showing consequences of water floods, hyperconcentrated flows, and debris flows. The most recent and well documented event occurred in December $24^{\text {th }}, 1995$ (Figure 2). Pellerin et al. [5] described that December, 1995 showed very low precipitation and high temperature (La Niña event in southern Brazil). In these conditions, a fourth polar front migrated from Argentina, Uruguay and southern Brazil, acting mainly over the continent. Stratified clouds were responsible for widespread, low intensity precipitation. However, low altitude ( $\pm 600 \mathrm{~m})$ cumulonimbus clouds migrated from the Atlantic Ocean toward the Aparados da Serra scarps ( $\pm 1200 \mathrm{~m}$ altitude). This resulted in concentrated, high intensity rainstorms. The records show precipitations as high as $400 \mathrm{~mm}$ for 24 hours period. Those records do not measure lower periods of time; but, it is known that the main part of that precipitation were established in periods less than 1-2 hours.

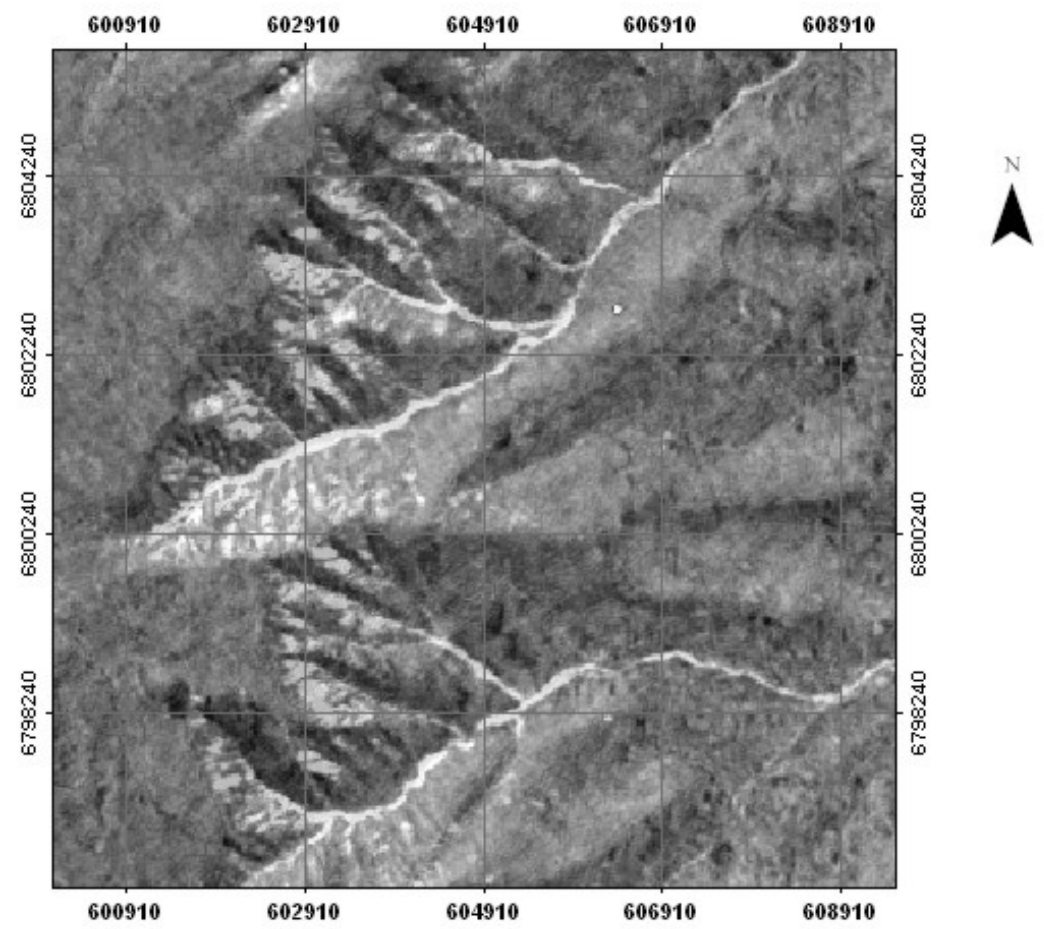

Figure 2: LANDSAT image showing the location of the $24^{\text {th }}$ December, 1995 debris flow event in Aparados da Serra region. The image results from (RGB composition TM5-97B1/TM5-94B1 : TM597B1 : TM5-94B1). Clear areas represent the December 1995 debris flow erosion and deposition. 
Recent localized debris flow events (e.g. February, 2003, 2006 and January, 2008) were also related to large periods of very low precipitation and high temperature. The magnitude and intensity of such events are still being investigated.

\section{Debris flow model for Aparados da Serra region (Brazil)}

The geologic-geomorphologic model for triggering the debris flows were developed based on geological mapping, digital terrain modelling and geotechnical soil and vegetation mapping. The model also incorporates the precipitation regime for the Aparados da Serra region.

The Aparados da Serra scarp is mainly developed upon sandstones (Botucatu Fm.) and basalts and dacites (Serra Geral Fm.) of the Paraná Basin, after the break-up of the Gondwana Supercontinent and the opening of the South Atlantic Ocean. The $1000 \mathrm{~m}$ scarp has a large number of $\mathrm{V}$ shaped valleys and small basins to collect the debris flowing downstream. The scarp is made up by a series of steps developed by geomorphological evolution of the volcanic flows (Figure 3 ). The soils resulting from denudation accumulate as colluvionar prisms over the platforms. The soils are mainly composed by clays, and some of them show latteritic features.

The upper part of the debris flow structures in the Aparados da Serra region are located in the higher scarp, or in the well exposed steps of the volcanic flow in the middle scarp. The high hydraulic gradients in the upper scarp and the low hydraulic conductivity for the soils enable runoff water flow during intense rainstorms. The water flowing in the groundsurface produces cascades at scarp steps, giving rise to slope steepening by erosion of colluvionar soils. The runoff water flow and slope steepening by erosion are the main mechanisms that triggers debris flows in the Aparados da Serra region during intense rainstorms. These processes can originate small, shallow landslides; it is believed that, after initial mobilization, a complex sequence of processes take place [6]. Finally, it is important to note that upper part of the debris flow scars in the Aparados da Serra region do not show clear elliptical-shaped failure surface.

\section{Debris flow modelling through GIS}

The GIS modelling was performed to define "where debris flows initiate and where they can deposit". According the geologic-geomorphologic model described above, the attempt was to determine the water and sediments flow distribution, in order to predict erosion and deposition patterns in the Aparados da Serra region. The modelling algorithm was based in the Unit Stream Powerbased Erosion Deposition (USPED, Mitasova and Mitas [4]). Taking into account the 2D form, the erosion/deposition prediction model was calculated through

$$
E D=\nabla(T . \mathbf{s})=\partial\left(T^{*} \cos a\right) / \partial \mathrm{x}+\partial\left(T^{*} \sin a\right) / \partial \mathrm{y}
$$

where $s$ is the unit vector in the steepest slope direction and $a$ is the terrain aspect. The model assume that sediment flow can be estimated by sediment transport capacity $(T)$ as

$$
T=R K C P A^{m}(\sin b)^{n}
$$


Monitoring, Simulation, Prevention and Remediation of Dense Debris Flows II 93

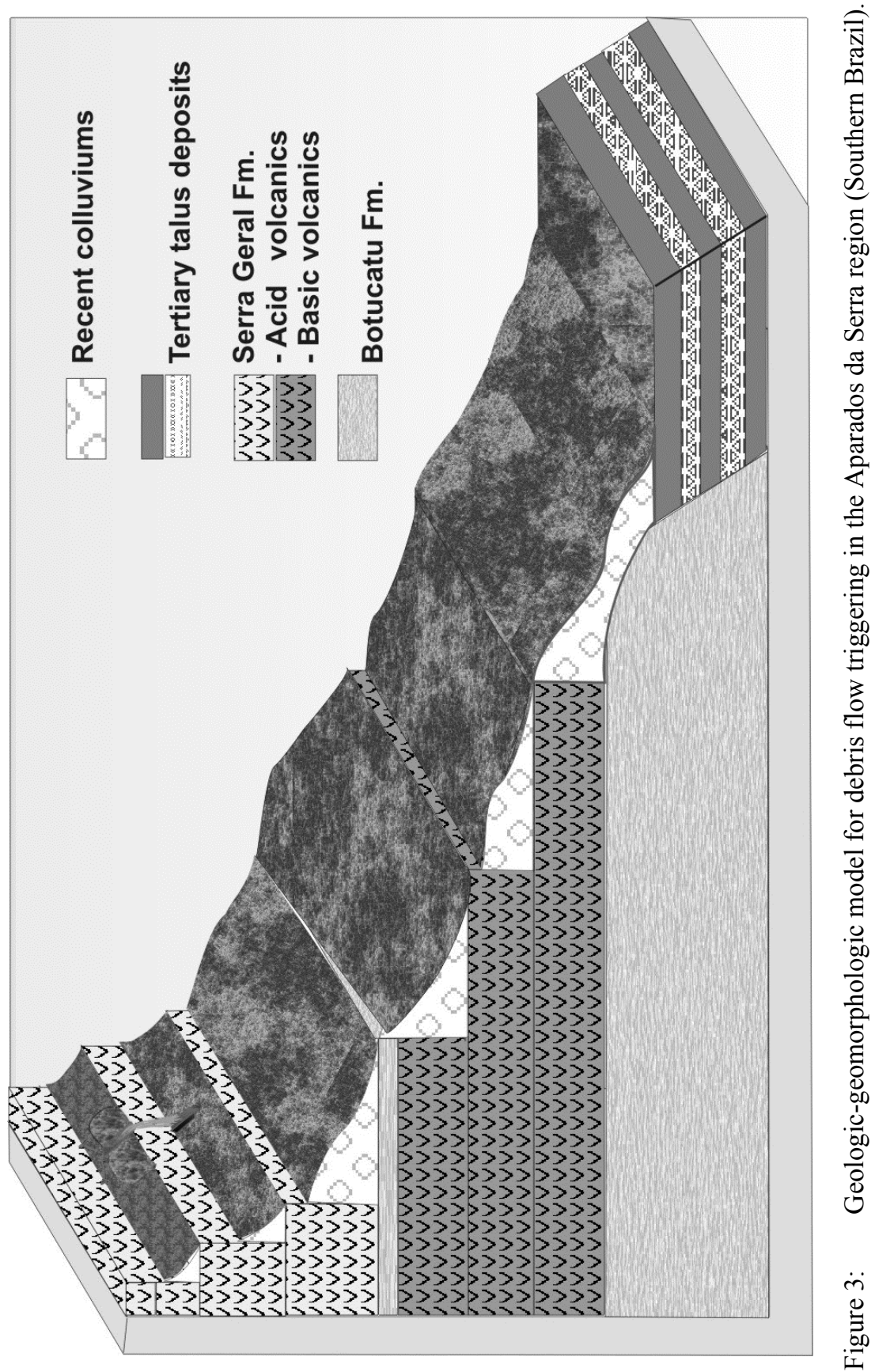

WIT Transactions on Engineering Sciences, Vol 60, (C) 2008 WIT Press www.witpress.com, ISSN 1743-3533 (on-line) 
where $R$ is the rainfall and runoff erosivity index due to mean annual precipitation, $K$ is the soil erodibility parameter related to physical and chemical properties of soils, $C$ and $P$ are parameters related to vegetation cover and management and soil uses and conservation practices, $A$ is the slope area considered into calculation, $b$ is solpe, $m$ and $n$ are constants related to runoff water and to soil types.

$R$ parameter is calculated by the sum of erosion index (EI) values over a year divided by 100 . The erosion index (EI) is a product of the kinetic energy of the falling raindrops and its maximum 30 -minute period intensity. $\mathrm{R}$ parameter for Aparados da Serra region was calculated for a 26 years period of daily records. The mean R parameter for Aparados da Serra region is 680 .

Soil erodibility parameter $(K)$ measures the susceptibility of a given soil to erosion by rainfall and runoff. This parameter was modified to express soil types and geology (geotechnical map). Each geotechnical unit shows different amount of sand, silt, clay and organic matter, which were used to compute their GEO parameter (Table 1).

$C$ parameter results from Atlantic forest cover mapping in the Aparados da Serra region, and from LANDSAT image classification procedures that distinguished between urban areas, cultivations, forest, forest plantations, grass fields, scarps, poorly vegetated areas, clouds, de-forested areas, and landslides. The computed $C$ parameters are shown in table 2 .

The soil uses and conservation practices parameter $(\mathrm{P})$ is used to account for the positive impacts of such agricultural management practices. However, there exist a number of conditions related to $\mathrm{P}$ parameter definition. Then, for the purposes of this project, $\mathrm{P}$ parameter value was defined as 1 , according criteria discussed by Renard et al. [7]. This value for $\mathrm{P}$ parameter is commonly used for steep terrains.

Table 1: $\quad G E O$ parameter computed for each geotechnical unit in the Aparados da Serra region (Southern Brazil).

\begin{tabular}{|c|c|c|c|c|c|}
\hline Geotechnical unit & Sand & Silt & Clay & $\begin{array}{c}\text { Organic } \\
\text { matter }\end{array}$ & $\begin{array}{c}\text { GEO } \\
\text { parameter }\end{array}$ \\
\hline Unit 1 & 7.7 & 54.2 & 34.8 & 3.2 & 0,317 \\
\hline Unit 2 & 19,2 & 48,1 & 28,9 & 3,8 & 0,325 \\
\hline Unit 3a & 7,5 & 23,3 & 63,4 & 5,8 & 0,272 \\
\hline Unit 3b & 22,5 & 38,5 & 35,3 & 3,7 & 0,301 \\
\hline Unit 4a & 89,2 & 5 & 5 & 0,8 & 0,176 \\
\hline Unit 4b & 31,4 & 27,6 & 36,2 & 4,8 & 0,291 \\
\hline Irati Fm. & 5,9 & 49,8 & 42 & 2,4 & 0,283 \\
\hline Estrada Nova Fm. & 2 & 42,2 & 54 & 1,9 & 0,248 \\
\hline
\end{tabular}

The geologic-geomorphologic model discussed above accepts runoff water turbulences to promote rill and gully erosions as triggering mechanism to debris flow. In this way, the $m$ and $n$ are constants for overland flow were set to $m=1.6$, and $n=1.3[8]$. 
Table 2: $\quad C$ parameter computed for different vegetation cover in the Aparados da Serra region.

\begin{tabular}{|l|c|}
\hline \multicolumn{1}{|c|}{ Classes } & $C$ parameter \\
\hline Cities (urban areas) & 0,500 \\
\hline Cultivations & 0,600 \\
\hline Forest from 170 to 390 m high & 0,083 \\
\hline Forest from 390 to $650 \mathrm{~m}$ high & 0,085 \\
\hline Forest from 650 to $1010 \mathrm{~m}$ high & 0,086 \\
\hline Forest from 1010 to $1135 \mathrm{~m}$ high & 0,088 \\
\hline Forest from 1135 to $1200 \mathrm{~m}$ high & 0,087 \\
\hline Forest plantations & 0,150 \\
\hline Grass fields & 0,100 \\
\hline Scarps & 0,450 \\
\hline Poorly vegetated areas & 0,450 \\
\hline Clouds & 0.000 \\
\hline De-forested areas & 0,450 \\
\hline Landslides and debris flow scars & 0.600 \\
\hline
\end{tabular}

\section{Debris flow susceptibility map in Aparados da Serra region (Brazil)}

The modelling was performed in ArcGIS software (ESRI), including Spatial Analyst routines. The modelling procedures were based in Mitasova et al. [9]. The coordinate system is referred to SAD69/96. The data for modelling were input in GeoUSPED file and included the DTM, the $R, G E O, C$ and $P$ parameters maps.

The DTM were developed using ASTER image through AsterDTM routine included in ENVI software. The spatial resolution was set in $15 \mathrm{~m}$, and altitudes vary from 0 to $1430 \mathrm{~m}$ high.

The modelling result was divided into 4 classes: $i$ ) areas susceptible to erosion, ii) areas susceptible to deposition, iii) areas that show pattern interference (erosion/deposition), and $i v$ ) stable areas. The classified map was exported to ENVI software in order to improve the spatial consistency of the results through grouping analysis tools. A $5 \times 5$ filter was used to group similar data. The debris flow susceptibility map (Figure 4) distinguishes the erosion from deposition areas.

\section{Discussion}

The GIS modelling using modified USPED procedure could distinguish areas susceptible for erosion and for deposition of the debris in steep scarps, such as Aparados da Serra (Southern Brazil). This result is mainly due to the physical parameters included in GIS modelling: slope, terrain aspect, rain intensity, hydraulic gradients, vegetation cover, geologic-geotechnical conditions. All of 


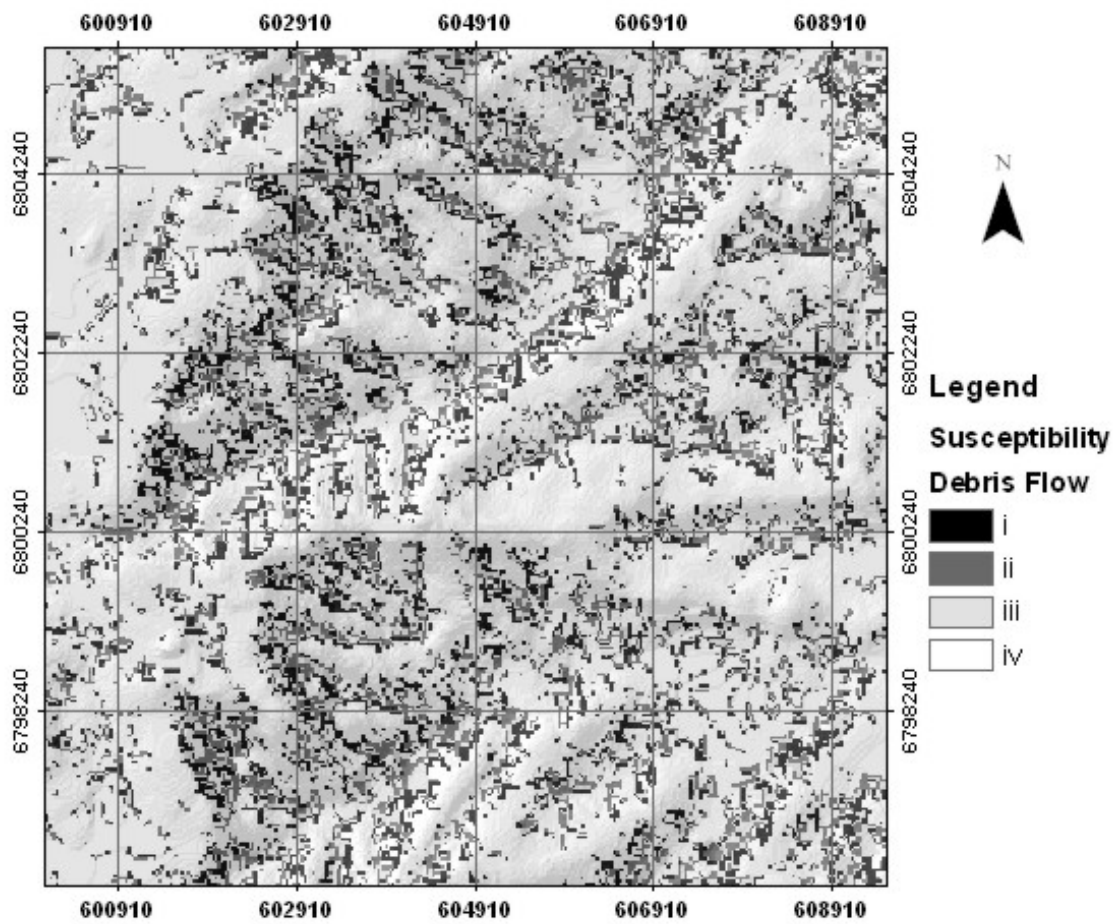

Figure 4: Debris flow susceptibility map for Aparados da Serra region (Southern Brazil). Classes: I - erosion; II - deposition; III transitional: erosion/deposition; IV - stable.

them are very important controlling factors for both classical erosion processes and debris flow processes. It is to be remembered that a complex cascade of processes can trigger debris flow [6], and such a condition is envisaged for Aparados da Serra region.

This result (Figure 4) was compared with the large debris flow event that took place in December 1995 (Figure 2), and also recent small scale and localized debris flow events that are still under evaluation. All these observed debris flows show good correlation with predicted area of occurrence. Thus, it can be concluded that such GIS modelling can be applied to predict areas "where" erosion and deposition of debris can take place during concentrated convective rainstorms. The investigations are to be developed to answer "when" debris flow can occur and "how big" the debris flow can be.

\section{Acknowledgements}

The authors want to thanks FINEP, PETROBRAS and TBG (Proc. No. 0682/01) for research funds that supported this investigation. 


\section{References}

[1] Costa, J.E., Rheologic, geomorphic, and sedimentologic differentiation of water floods, hyperconcentrated flows, and debris flows. Flood Geomorphology, ed. V.R. Baker, R.C. Kochel, and P.C. Patten, John Wiley and Sons, New York, p. 113-122, 1988

[2] Iverson, R.M., Schilling, S.P. \& Vallance, J.W., Objective delineation of lahar-inundation hazard zones. GSA Bulletin, 110(8), pp. 972-984, 1998

[3] Morton, D.M., Alvarez, R.M. \& Campbell, R.H., Preliminary Soil-Slip Susceptibility Maps, Southwestern California, U.S.G.S. Open-File Report OF 03-17, 14 pp., 2003

[4] Mitasova, H. \& Mitas, L., Distributed soil erosion simulation for effective erosion prevention. Water Resources Research 34(3), pp. 505-516, 1998. Erosion/Deposition modeling with USPED tutorial, skagit.meas.ncsu. edu/ helena/gmslab/erosion/usped.html

[5] Pellerin, J., Duarte, G.M., Scheibe, L.F., Mendonça, M., Buss, M.D. \& Monteiro, M.A., Timbé do Sul - Jacinto Machado: avaliação preliminar da extensão da catástrofe de 23-24/dec/1995. GEOSUL, Florianópolis (Brazil), 12(23), pp.71-86, 1997.

[6] Iverson, R.M., The physics of debris flows. American Geophysical Union, Reviews of Geophysics, 35(3), pp.245-296, 1997.

[7] Renard, K.G., Foster, G.R., Weesies, G.A., McCool, D.K. \& Yoder, D.C., Predicting spoil erosion by water: a guide to conservation planning with the revised universal soil loss equation (RUSLE). Agriculture Research Service. Agriculture Handbook Number 703, 384 pp., 1996

[8] Foster, G.R., Process-based modelling of soil erosion by water on agricultural land. Soil Erosion on Agricultural Land, edited by J. Boardman, I.D.L. Foster \& J.A. Dearing, John Wiley \& Sons Ltd, pp. 429-445, 1990

[9] Mitasova, H., Brown, W.M., Hohmann, M. \& Warren, S., Using soil erosion modeling for improved conservation planning: a GIS-based tutorial. Geographic Modeling Systems Laboratory, University of Illinois, http:// skagit.meas.ncsu.edu/ helena/gmslab/reports/CerlErosionTutorial, 2002 